\title{
Factors Influence on Tourists' Satisfaction of Urban Marketing in Mongolia
}

\author{
Yi Hsu \\ Associate Professor, \\ Department of Business Administration \\ National Formosa University \\ Huwei, Yunlin \\ Taiwan \\ Sugaraa Khurelbaatar \\ Graduate Student \\ Department of Business Administration National Formosa University \\ Huwei, Yunlin \\ Taiwan
}

\begin{abstract}
This study aimed to determine what factors influence on tourists' satisfaction during visiting the city in Mongolia. The data had been collected from domestic and foreign tourists who were visit the city and the hypotheses were tested by applying LISREL8.8 with covariance matrix. The results depicted only one hypothesis was supported and others were rejected. City infrastructure positively impacts on tourists' satisfaction was supported. Other independent variables were city reputation, attraction, workforce, economy, street marketing, and destination marketing without significant influence on tourists' satisfaction.
\end{abstract}

Keywords: city reputation; city infrastructure; city attraction; city workforce; city economy; street marketing; destination marketing; tourist satisfaction

\section{Introduction}

\subsection{Research background}

In the 21th century, urbanization has intensified in worldwide, with the number and quality of cities and their populations growing rapidly. Currently, almost $55 \%$ of the world's population lives in urban areas and according to the 2018 Revision of the World Urbanization Prospects by UN estimated that by 2050 it will grow to 68\%. The city is the center of civilization and social development. Urbanization is intensive and tourism industry is expanding as cities are looking for their own way to develop, although focusing on the image is becoming increasingly important, so the countries are building their own city brand. If the city is good, which means this city with the convenience for residents and the attractions for tourists and entrepreneurs, and has positive influence on the satisfaction for citizens and visitors. The city is a comprehensive center for education, innovation, politics, technological advance, social service, and financial that provides favorable conditions for human development (Sandui,2015). Local migration, technology advancements including that required a lot of factors from the competitiveness of cities, such as transportation, job creation, cultures, tourists' attractions, etc...(Kotler, 2002). Since the 19th century governments had begun an experiment to city marketing (Ward, 1998), but over the past few decades, major cities had used marketing more widely in cities so that created competition among investors, tourists, and residents (Kotler, Asplund, Rein, \& Heider, 1999).In our country, even though has "nomadic" civilization, but this global trend creating an urban civilization since the mid-20th century in Mongolia. Almost 50\% of Mongolia's population lives in the capital city of Ulaanbaatar, that compared with other cities who have hundreds of year of history in around the world, it is a relatively young city cause has a number of criticisms such as quality of service and infrastructure. Table 1.1 shows that population of Mongolia.

\section{Table1.1: Population of Mongolia}

\begin{tabular}{|l|l|l|l|l|l|}
\hline & 2014 & 2015 & 2016 & 2017 & 2018 \\
\hline Population of Mongolia & $2,963.1$ & $3,026.9$ & $3,088.8$ & $3,148.9$ & $3,208.1$ \\
\hline Population of Ulaanbaatar & $1,367.5$ & $1,379.6$ & $1,418.3$ & $1,451.7$ & $1,477.2$ \\
\hline Resident Population of Ulaanbaatar & $1,290.7$ & $1,330.0$ & $1,363.1$ & $1,399.0$ & $1,431.0$ \\
\hline
\end{tabular}


The city is civilization center for education, innovation, politics, economy, technological advancement, and social development that provide favorable conditions for human development. (Sandui, 2015). Our country has low urban development and infrastructure, which is diminishing both of the quality of life and the competitiveness of the city's economy. Therefore, urban marketing and infrastructure will help a city become the most comfortable place for residents and tourists, attract new investment, enhance the quality and competitiveness of the territory. Tourism had provided one of the fastest-growing socio-economic sectors over the last few decades, with significant impact on urban development. Nowadays, tourism is not just for entertainment and leisure, which has a positive impact on local development, especially in urban development.In the last 2018, 598 thousand tourists visited in our country, there were 92 percent of tourists came to the capital city of Ulaanbaatar also passed through (NSO).Table 1.2 shows the number of foreign visitors arrived in the Mongolia.

Table 1.2 Number of Foreign Visitors arrived in the Mongolia

\begin{tabular}{|l|l|l|l|l|l|}
\hline & 2014 & 2015 & 2016 & 2017 & 2018 \\
\hline America & 19,131 & 19,607 & 21,949 & 24,096 & 25,767 \\
\hline $\begin{array}{l}\text { East Asia and } \\
\text { Pacific }\end{array}$ & 359,397 & 320,191 & 303,255 & 345,648 & 372,876 \\
\hline Europe & 119,969 & 120,089 & 138,152 & 164,392 & 189,161 \\
\hline Middle East & 3,766 & 4,013 & 3,830 & 3,884 & 4,806 \\
\hline South Asia & 2,295 & 2,329 & 2,876 & 3,127 & 3,909 \\
\hline Africa & 1,126 & 982 & 1,165 & 1,520 & 1,848 \\
\hline total & 505,684 & 467,211 & 471,227 & 542,667 & 598,367 \\
\hline
\end{tabular}

\subsection{Research purpose and objective}

In Mongolia, the number of tourists increasing year by year, however in the tourism sector service quality and accessibility are still low which may have negatively affected on the satisfaction of domestic and foreign tourists visiting the capital city of Ulaanbaatar. Tourism is becoming more sustainable, accessible and accountable in each direction day by day, because that tourism has a lot of influence on creating new changes in the urban area. Building a positive and innovative marketing approach to tourists is a key factor of tourism development and also urban development. It can help us to gain competitive advantages to compete with major cities. Although, there are many literatures had studied urban tourism development, but very few studies for urban marketing in Mongolia. According to the motive research background, this study aimed to determine what factors influence on the tourists' satisfaction of city marketing. Thus, this study investigates tourists who had visited Ulaanbaatar and in order to develop new products and services for tourists demand and need. This study also provided useful information for strategic of urban marketing.

\subsection{Research Structure}

This paper consists of five chapters.

Chapter 1 introduces the background, the purpose of this research, and research structure.

Chapter 2 shows the literature review which is city marketing and tourism satisfaction and the chapter present the hypotheses of the research.

Chapter 3 describes the methodology of the research. In this research, data collected through using the paper survey and online survey with who had visited in Ulaanbaatar city.

Chapter 4 presents the analysis of data and results and the final chapter offers a summary of the research with conclusion and discussion.

\section{Literature Review}

\subsection{Urban Marketing}

The definition of urban marketing is the creation, dissemination, and activation of the city by organizing targeted activities to attract tourists, residents, and businesses. Urban marketing is also frequently mentioned as one of the reasons for hosting a particular event in a city. And the city image effects on citizens' living, investing and travel decisions(Kotler, Gertner, 2002).Also, it makes a great image for residents and foreign partners to connect with all the information from localities. The concept of image is that the common belief of the local community; mostly geographical location, culture, history, art, celebrity, and other factors influence the image creation. Rather, entertainment and media are the strongest effects on people's perceptions and beliefs in the area. Today, countries are building their own city brands that aim to attract tourists and businesses. 
In particular, the tourism industry has developing currency revenue and employment creation, as one of the leading sector of economy, while to maintain different image building strategies for specific target groups by using strategic image management in order to attract tourists, expand the market. For example, to pursue a different strategy for tourists, residents, and entrepreneurs, which would help to allow those groups to make positive perceptions about the city.Many of marketing literatures had emphasized on promoting urban development and increased competitiveness, there are number of factors to consider that aimed to improve urban development such as housing area, construction, environment, and employment, which is responsible for ensuring mutual cooperation for all the parts(Koster, A.1994).In this sector, the examples of the cities have more implements of urban marketing such as the US and some countries in Europe; which is New York, Paris, Barcelona, Vienna, Berlin and Amsterdam such that they continue to develop their own different way. According to Jan van der Meer (1990), urban marketing is defined to suggests, that oriented activities to coordinate between demand and urban activities, for residents, local companies, tourists and other guests. In general, City Marketing as for combining with local features and service quality, by creating efficient, accessible, and attractive services, also building special features and images to show the city's advantages. There are some factors influence on the ability of attracting the public and investors to local area such as regional development, image, and reputation (Drill, 2016). Also, it is important to focus on creating a good image that satisfy with customer satisfaction as suitable on target groups' needs.

According to Braun (2008) study, the several basic strategies are most used: 1. City image, creates a positive city image for investors and tourists, which aimed to create and increase the city's reputation. 2. Attractiveness, intends to enhance interest, and increase tourists' attraction, 3. Infrastructure, which is the basis of the city's construction, that often refers to electricity, water, telecommunications, transportation, security, airport, hotel, stadiums, and road etc. Based on the above, the following factors could influence on consumers' satisfaction of urban marketing: city reputation, city attractiveness, city infrastructure, city workforce, city economy, street, and destination.

\subsubsection{City Reputation}

The reliable information about the city, as to emerge over a long period of time, characteristics of life, and the activities in the city are represented for the city reputation. Reputation marketing is a strategy that is evaluated by public emotions to promote city awareness in order to increase visitors (Zhang\& Zhao, 2009). The public emotions are defined by the territorial function, security, and environment, which including heritage monuments, investment benefits, and urban economic development(Drill, 2016; Govers,2011; Morrello \& Ratti2009).

\subsubsection{City Infrastructure}

The infrastructure is transportation and communication(Goletti \& Christina-Tsigas, 1995), but nowadays, the urban infrastructure is constantly evolving and is multilateral understanding of engineering system, that including many sectors such as the economy, society, environment, and science (Ferrer, Thomé, \& Scavarda 2018) .Gearing (1974), defined infrastructure issues including roads, water, electricity, safety, health, telecommunications, and public transportation service as key factors. Crouch, Winklhofer, and Hamilton (2006) also considered the tourism infrastructure as materiality and organizational consist, that divided into four facilities which are accommodation, food or beverage, accompanying, and communication. In order to improve infrastructure by the government, it is important to support that stay long time period, focus on the number of visitors, increase spending, and create additional locations for tourist-oriented services (Conejo \& Wooliscroft, 2015). Developing good infrastructure is related to supporting good service quality and employment. (Prideaux, 2000).

\subsubsection{City Attractiveness}

Attractive marketing is a distinctive element that depending on the geographical characteristics to get attention, such as location, climate, history, culture, unique formations or built-in, activities, events, and forms of entertainment service(Crouch, 2011; Ritchie\& Crouch, 2003; \& Yuksel, 2001). According to researchers (Deas \& Giordano, 2001) attractiveness creates competition for destinations, which contributes to the socio-economy and the improvement of the living standards and social welfare of the population (Hanafiah, Hemdi, \& Ahmad, 2016).

\subsubsection{City Workforce}

The service quality depends on the communication, knowledge, skills, and appearance of employees (Meyer, 1999), and consumers based on their own experience to assess by polite service or professional skills, that becomes an important indicator of the service sector (Hunt,1977). In addition, to creating a desire to buy and promote products and services to consumers, that the organizations can promote their products and services through famous celebrities or spokesperson, as for that can help to create a positive attitude towards the behavior of consumers (Anon, 2008). According to researchers (Lacobucci \& Ostrom, 1996, and Woodside Frey\& Daly, 1989) if the quality of service is good, fast, secure, and responsive, it is assumed that customer gets high satisfaction and loyalty. 


\subsubsection{City Economy}

Urban development directly depends on the following factors; such as geography, population, technological advancement, transportation opportunities with other places, and major economic sectors. Cities are important for development of country's economy, especially roles of urban tourism, which has positive effects on circulation of currency, increasing demand for foreign trade, employment, and development of national production (Enkhzaya, 2014). Hence, consistent for tourist needs, that trade or service, activities, hotel, restaurant, and entertainment, for that required to develop a complex of tourism. Tourist spending by tour operators affects the economy through the following channels, these include:Other business sectors - suppliers of products and services for tourism business, households income of employees in tourism and tourism promotion, government - Taxes from tourists, businesses and households (Tulyeu,, 2012).

\subsubsection{Street}

The street is a comprehensive set of elements, such as road, a light of road, traffic, ground or underground infrastructure, green building, street design and, street names (Grossett, 2017). Street is also one of the factors influencing urban development, with a great indicator of social and human relationships, as well as citizen's education, knowledge, and culture. The main feature of street marketing is to support products and services at street or public area (Cova, Saucet, 2014), that different from advertisement, which possible to communicate directly with the customers (Levinson, 1998).

\subsubsection{Destination}

The destination marketing impact on cities development.According to Blain, Levy, and Ritchie (2005), the revised definition of destination marketing is as follows; 1. A name, symbol, logo, word mark and other graphics are easy to differentiates the different destinations; 2 . The uniquely associated between destination and memorable travel; 3 . the psychological connection between the traveler and the destination; 4. saving travelers time and reduce perceived risk. These activities positively influence on visitors' destination choice that serves to create a destination image. The advantage of destination is increasing utilization that distinguish between two similar dimensions, increasing customers destination loyalty, and increasing profit for stakeholders, which are local tourism businesses and travel intermediaries. The benefits for visitors as include easy to making decisions, reducing search costs, reducing the risk, and enhancing the experience (Morgan, Pritchard \& Pride 2004).

\subsection{Tourist Satisfaction}

For tourism, tourists' satisfaction is the expectation of a given product and service, also the reality of after journey or conclusion of the experience which generated from the predictions (Baker and Crompton, 2000). Tourists satisfaction is based on a theory of belief, consider that expectation compare with the perceptions (Kotler and Keller, 2007).History, culture, and climate are important to the loyalty of the visitors and their positive impressions, but also hotel and food as terms of services are considered to be more important (Rajesh, 2013 \& Coban, 2012). In the other hand, it would help to support the competitiveness of entrepreneurs in the tourism industry (Kozak \& Rimmington. 2000). According to Hunt, (1977), satisfaction was not only gained a good experience, as well as evaluation at least as good as it should be. Therefore, customers more satisfied with the situation that if their experience is better than their expectations (Yuksel\& Yuksel, 2001).

\section{Figure 2.1 Research model}

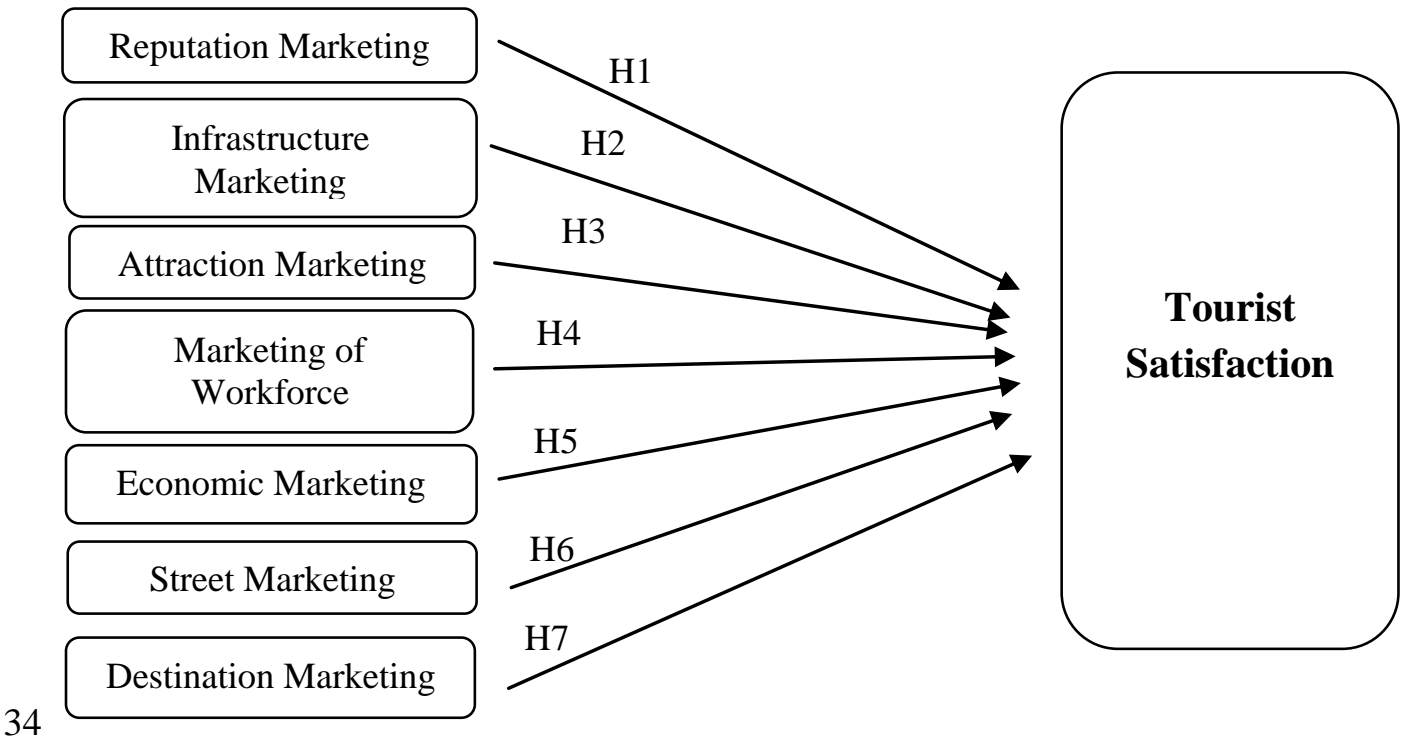




\subsection{Hypotheses}

Preliminary assessment of service quality is uncertain, so the reputation is executed an important role for the service market (Wang, Lo, \& Hui, 2003). Most tourists care about the reputation of the destination, which reduces the risk of having non-interest (Morgan, Pritchard, \& Pride 2011). In marketing literatures, the company's reputation and customer satisfaction are with a strong impact on each other (Chang, 2013;Walsh, 2006). Based on above literatures, this study proposed the following hypothesis: $H_{1}$ : City reputation positively impacts on tourists' satisfaction.

Susskind, Alex, \& Carl (2000) argued that infrastructure is the most important influence on tourists' satisfaction. Malthouse, Oakley, Calder, \& Iacobucci(2004), tourists have great satisfaction for comfortable living condition, outside activities, and attractive buildings, andthey would like to share their experience with others (Moscardo, 2017).Sothe following hypothesis was suggested: $\mathrm{H}_{2}$ : City infrastructure positively impacts on tourists' satisfaction.

The positive psychological effects of tourist are dependent on the location and function of the land (Prayag \& Ryan, 2012; Ramkissoon, Weiler, David, 2013 and Veasna, Wu, \& Huang, 2013).According to Yuksel \& Yuksel (2010), the people of the area, services, and atmosphere of the community help create a positive sense of identity for the individual. Based on above research, this study proposed the following hypothesis: $H_{3}$ : City attraction positively impacts on tourists' satisfaction.

Good service quality is important to customer satisfaction and loyalty. (Lacobucci \& Ostrom 1996). One of the key factors for determining visitor satisfaction is the relationship between workers and tourists (Hunt, 1977). So the following hypothesis was suggested: $H_{4}$ : Workforce of city positively impacts on tourists' satisfaction.

To restore the urban economy contributed by the government, increasing the demand of historical and cultural monuments would influence on the visitors' satisfaction (Tulyeu, 2012). Tourists' satisfaction influenced by urban GDP and the overall economic level of the city, according to Zhou, Liu, and Tang (2018).So the following hypothesis was suggested: $H_{5}$ : City economic positively impacts on the tourists' satisfaction.

Sandybayev (2018), pointed out that the types of street festivals have positive effects on satisfaction, as well as the positive aspects of promoting activities that have a positive impact on the behavior and satisfaction of the guests. Therefore, the following hypothesis was proposed: $H_{6}:$ Street Marketing has positively impacts on tourists' satisfaction.

Truong et al. (2017), depicted the special features of destination is a positive influence on visitor satisfaction, also according to a survey by foreign tourists' satisfaction in Ulaanbaatar, which saving the tourists time and the destination signs are clear, that positively affected on tourists' satisfaction. So the following hypothesis was suggested: $H_{7}$ : Destination Marketing has positively impacts on tourists' satisfaction.

\section{Methodology}

This study aimed to understand which factors of city marketing influence on tourists' satisfaction.

\subsection{Questionnaire}

In this study, the data was collected from domestic and foreign tourists who visited in Ulaanbaatar through a number of companies offering domestic travel in the tourism industry in Mongolia. The survey questionnaire were obtained 225 samples from domestic and foreign tourists, which among 208 responses were valid for further analysis. The questionnaire had developed in two languages, English and Mongolian, which consists of 3 parts. The first part of the questionnaire was contained the city marketing, measured in seven factors with 66 questions, which are city reputation, city infrastructure, city attraction, city workforce, city economy, street, and destinations, each question measured on five-point Likert scales, ranging from $1="$ strongly disagree", to $5=$ "strongly agree". The second part measured the satisfaction of tourists with nine multiple-choice questions. The last part is included demographic characteristics of participants which are gender, age, education, and income. The questionnaire was distributed through the e-mail and social networking website, utilized design by a Google docs survey form. Table 3.1 indicated the questions as variables in this study and their literature resources. 
Table 3.1 Research measurement scales

\begin{tabular}{|c|c|c|c|}
\hline Factor & Variable & Author & \\
\hline \multirow[t]{7}{*}{ Reputation Marketing } & Conduct special events & Hsing (2010) & \\
\hline & Combine with local cuisine and special events & Chiang, & Weng, \\
\hline & Planning international events & \&Chang,(2012) & \\
\hline & The city can create international identification & & \\
\hline & Build the security reputation of the city & & \\
\hline & Enhance the overall environmental reputation & & \\
\hline & Culture assets protection & & \\
\hline \multirow[t]{7}{*}{ Infrastructure Marketing } & Strengthen basic people's livelihood construction & & \\
\hline & Enhance telecommunication technology & & \\
\hline & Building special stadium & & \\
\hline & Develop high-qualityenvironment & & \\
\hline & Redevelopment urban construction & & \\
\hline & Planning transportation service system & & \\
\hline & Beautify the city landscape & & \\
\hline \multirow[t]{7}{*}{ Attractive Marketing } & Development of local special industry & & \\
\hline & Provide tourists care service & & \\
\hline & Emphasize nature landscape & & \\
\hline & Create local culture reputation & & \\
\hline & Marketing the historical culture & & \\
\hline & Promote international events & & \\
\hline & Prolong tourists time to stay in city & & \\
\hline \multirow[t]{7}{*}{ Workforce Marketing } & Enhance consolidation by events & & \\
\hline & Sustain positive words of month & & \\
\hline & Integrate marketing drama and video & & \\
\hline & Invite idol to be spokesperson & & \\
\hline & Invite celebrity to be spokesperson & & \\
\hline & Friendly tourists reception & & \\
\hline & $\begin{array}{l}\text { Introduction and explanation by professional tour } \\
\text { guide }\end{array}$ & & \\
\hline \multirow[t]{7}{*}{ Economic Marketing } & Increase sales revenue of local cuisine & & \\
\hline & Increase sales revenue of local products & & \\
\hline & Aggressively development tourism industry & & \\
\hline & Enhance the exposure of the events & & \\
\hline & Increase utilization of hot scenes spots & & \\
\hline & Rebuild international culture & & \\
\hline & Expansion of the events & & \\
\hline \multirow[t]{3}{*}{ Street Marketing } & Target younger consumer & Grossett (2019) & \\
\hline & Promote a particular product or service & (Online Survey & from \\
\hline & Planning a parade & Survey monkey) & \\
\hline \multirow[t]{3}{*}{ Destination Marketing } & $\begin{array}{l}\text { A name, symbol, logo, word mark or other } \\
\text { graphics are makes easy to differentiates a } \\
\text { destination from the other destination }\end{array}$ & $\begin{array}{l}\text { Blain, Levy \& } \\
(2005)\end{array}$ & Ritchie \\
\hline & $\begin{array}{l}\text { The uniquely associated between destination and } \\
\text { memorable travel }\end{array}$ & & \\
\hline & $\begin{array}{l}\text { The psychological connection between the } \\
\text { traveler and the destination; }\end{array}$ & & \\
\hline
\end{tabular}

\subsection{Method}

In this study, LISREL ( Linear Structural Relation) is the basis of the theoretical model, to combined with Statistica 10.0 and Excel 2013 for processing the data, as follows; first, we analyzed the demographic data and tourist satisfaction data of the survey by Statistica 10.0 software and to compile the result in form of frequency and percentages. This study we used Microsoft Excel for creating the covariance matrix, that helps to estimate the boundary of the factors in the model. Then we, to test the hypothesis used CFA in LISREL 8.8 . 


\subsubsection{Confirmatory Factor Analysis}

CFA is a powerful statistical technique used to analyze the credibility of a relationship between observed variables and their latent variables exists. LISREL (Linear Structural Relationships) is suitable for complex, multi-level data such as providing influential and the estimated mean value among various group. LISREL provides many different of tools for structural equation modeling to determine how to conform the data.

\section{Result}

\subsection{Demographic data}

The demographic characteristics of the respondents were presented by a total of 208 participants, which comprised of $59(28,3 \%)$ domestic tourist and $149(71,7 \%)$ foreign tourist. Most of the survey respondents were female which are $51,4 \%$ (107 respondents), and 48,5\% (101 respondents) were male. In the age group 39.4\% respondents were between 26-35 years old, 37\% aged between 18-25 years old, 8.1\% age from 46-55 years old, age between 36-45 years old $5.7 \%$. Age group under 18 and over 55 years old respondents were $4.3 \%$. The number of respondents who had income $29.8 \%$ with 750,000-1,000,000 MNT and higher than 1.000.000 MNT and 30.7\% (64) of respondents were students. (See table 4.1)

Table 4.1 Descriptive statistics $(\mathrm{N}=208)$

\begin{tabular}{llll}
\hline Characteristics & Categories & Frequency & Percentage \% \\
\hline Nationality & Domestic tourists & 59 & 28.3 \\
Age & Foreign tourists & 149 & 71.7 \\
& Under 18 & 9 & 4.3 \\
& $18-25$ & 77 & 37.01 \\
& $26-35$ & 82 & 39.4 \\
& $36-45$ & 12 & 5.7 \\
Gender & $46-55$ & 17 & 8.1 \\
& Over 55 & 9 & 4.3 \\
Occupation & Male & 101 & 48.5 \\
& Female & 107 & 51.4 \\
& Student & 64 & 30.7 \\
& Service sector & 23 & 11.05 \\
& Financial sector & 35 & 16.8 \\
Income (MNT) & Manufacturing sector & 23 & 11.05 \\
& Public officials & 24 & 11.5 \\
& Government officials & 9 & 4.3 \\
& others & 30 & 14.3 \\
& Less than 250,000 & 10 & 4.8 \\
Did you think UB is & 250,001- 500,000 & 15 & 7.2 \\
ethical city for tourists satisfy? & Yes & 59 & 28.3 \\
(QD) & Ho0,001- 750,000 & 62 & 29.8 \\
& Higher than 1,000,000 & 62 & 29.8 \\
& & 153 & 73.5 \\
& No & & \\
& Maybe & 27 & 12.9 \\
& & 28 & 13.4 \\
\hline
\end{tabular}


Table 4.2 Covariance matrix of hypothesis model

\begin{tabular}{|c|c|c|c|c|c|c|c|c|}
\hline & 1 & 2 & 3 & 4 & 5 & 6 & 7 & 8 \\
\hline City & & & & & & & & \\
\hline Reputation & 0.197 & & & & & & & \\
\hline 2. City & & & & & & & & \\
\hline Infrastructure & 0.051 & 0.087 & & & & & & \\
\hline 3. City & & & & & & & & \\
\hline Attraction & 0.020 & 0.037 & 0.066 & & & & & \\
\hline 4. City & & & & & & & & \\
\hline Workforce & 0.049 & 0.062 & 0.048 & 0.130 & & & & \\
\hline 5. City & & & & & & & & \\
\hline Economy & 0.017 & 0.048 & 0.044 & 0.064 & 0.093 & & & \\
\hline 6. Street & & & & & & & & \\
\hline $\begin{array}{l}\text { Marketing } \\
\text { 7.Destination }\end{array}$ & 0.032 & 0.048 & 0.038 & 0.078 & 0.056 & 0.118 & & \\
\hline Marketing & 0.006 & 0.017 & 0.031 & 0.019 & 0.040 & 0.052 & 0.137 & \\
\hline 8. Satisfaction & 0.015 & 0.052 & 0.035 & -0.003 & 0.017 & 0.010 & 0.023 & 1.615 \\
\hline
\end{tabular}

Table 4.2 pointed out the covariance matrix which was calculated by Excel 2013. Covariance Matrix describe the linear covariance between two variables. A positive value represents a trend of the linear relationship while the negative figure displays the decreasing of the linear relationship.

\subsection{Confirmatory factor analysis testing}

Table 4.3 Goodness of fit statistics measurement

\begin{tabular}{lll}
\hline Fit measures & Statistics measurement target & Values \\
\hline$\chi^{2}$ & smaller grades is better & 0.00 \\
p-value & greater than 0.05 & 1.0 \\
RMSEA & $<0.08$ & 0.000 \\
\hline
\end{tabular}

The Weighted Least Squares Chi-Square and RMSEA were significant $\left(X^{2}=0.00\right.$, RMSEA $\left.=0.000, p=1.00\right)$. The data were collected from the customers of the tourism company in Ulaanbaatar Mongolia. By utilizing LISREL to test the good of fit of the model, this study tested the hypotheses at the same time. RMSEA is the residual measurement for the model and the less RMSEA means the smaller error and the better good of fit for the model. The results depicted the model is perfect good of fit with $\left(\mathrm{X}^{2}=0.00, \mathrm{RMSEA}=0.000, \mathrm{p}=1.00\right.$

\subsection{Hypothesis testing and structural model}

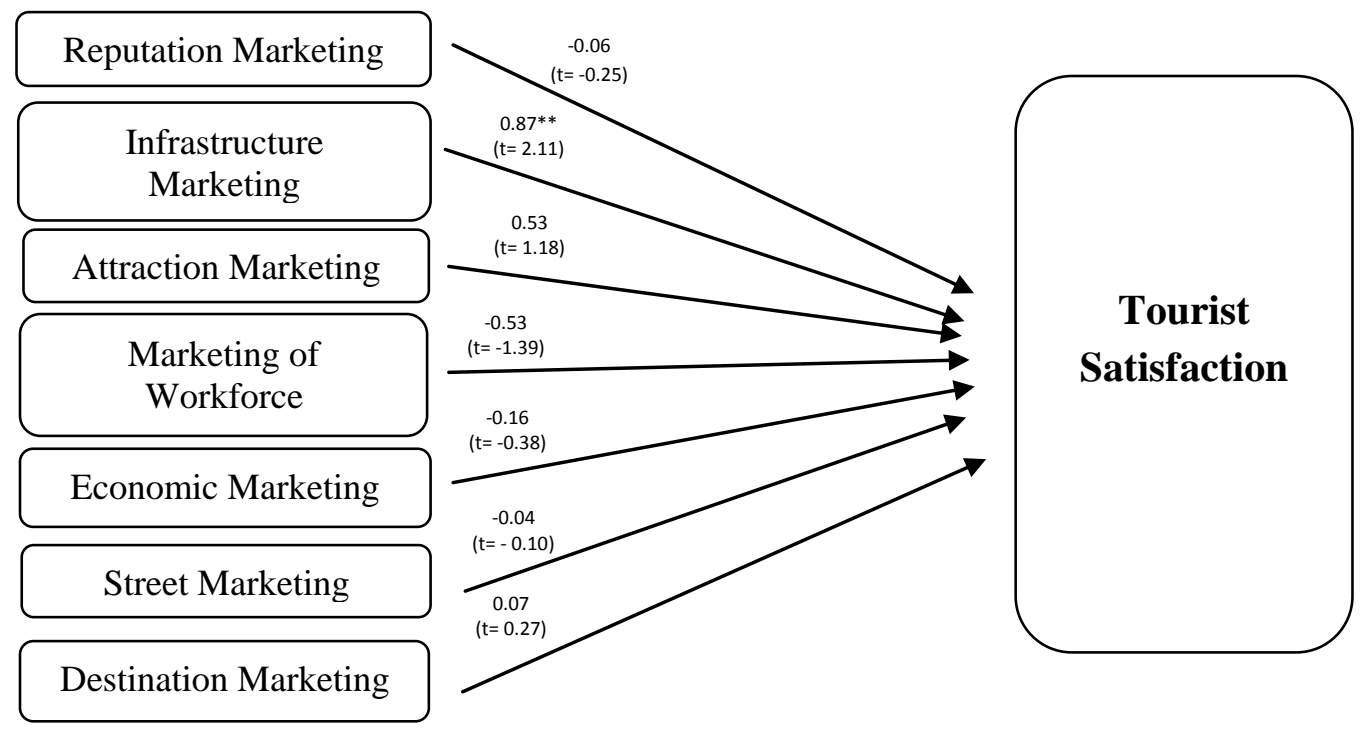


Table 4.4 Hypothesis result

\begin{tabular}{llll}
\hline Hypothesis & Estimates & t-value & Result \\
\hline $\mathrm{H}_{1}:$ City reputation $\longrightarrow$ Tourist satisfaction & -0.06 & -0.25 & rejected \\
$\mathrm{H}_{2}:$ City infrastructure $\longrightarrow$ Tourist satisfaction & 0.87 & 2.11 & supported \\
$\mathrm{H}_{3}:$ City attraction $\longrightarrow$ Tourist satisfaction & 0.53 & 1.18 & rejected \\
$\mathrm{H}_{4}:$ City workforce $\longrightarrow$ Tourist satisfaction & -0.53 & -1.39 & rejected \\
$\mathrm{H}_{5}:$ City economy $\longrightarrow$ Tourist satisfaction & -0.16 & -0.38 & rejected \\
$\mathrm{H}_{6}:$ Street marketing $\longrightarrow$ Tourist satisfaction & -0.04 & -0.10 & rejected \\
$\mathrm{H}_{7}:$ Destination marketing $>$ Tourist satisfaction & 0.07 & 0.27 & rejected \\
\hline
\end{tabular}

Figure 4.1 and Table 4.4 described only one hypothesis $\left(\mathrm{H}_{2}\right)$ was supported and others were rejected. $\mathrm{H}_{2}$ : City infrastructure positively impacts on tourist satisfaction was supported (estimates=0.87, t-value=2.11). $\mathrm{H}_{1}, \mathrm{City}$ reputation positively impacts tourist satisfaction but the result was insignificant negative influence (estimates $=-0.06$, $t-$ value $=-0.25$ ), therefore $\mathrm{H}_{1}$ was rejected. $\mathrm{H}_{3}$, City attraction positively impacts on tourist satisfaction but the result was insignificant positive influence (estimates $=0.53$, t-value $=1.18$ ), hence $\mathrm{H}_{3}$ was rejected. $\mathrm{H}_{4}$, Workforce of city positively impacts on tourist satisfaction but the result was insignificant negative influence (estimates $=-0.53$, $t$-value $=-1.39$ ), therefore $\mathrm{H}_{4}$ was rejected. $\mathrm{H}_{5}$, City economic positively impacts on the tourist satisfaction but the result was insignificant negative influence (estimates $=-0.16$, $\mathrm{t}$-value $=-0.38$ ), so $\mathrm{H}_{5}$ was rejected. $\mathrm{H}_{6}$, Street marketing has positively impacts on tourist satisfaction but the result was insignificant negative influence (estimates $=-0.04$, $t$-value $=-$ 0.10 ) therefore $\mathrm{H}_{6}$ was rejected. $\mathrm{H}_{7}$, Destination marketing has positively impacts on tourist satisfaction but the result was insignificant positive influence (estimates $=0.07$, $\mathrm{t}$-value $=0.27$ ), hence $\mathrm{H}_{7}$ was rejected.

\section{Conclusions and Discussion}

\subsection{Conclusions and Discussion}

This study aimed to determine what factors influence tourists' satisfaction in during visiting on the city. The data had been collected from domestic and foreign tourists who were visit the city and the hypotheses were examined by using LISREL8.8 with Covariance Matrix. The results depicted only one hypothesis was supported and others were rejected. $\mathrm{H}_{1}$ : City reputation positively impacts tourists' satisfaction. The results did not supported $\mathrm{H}_{1}$ which had been supported by Zhang\& Zhao (2009), Morrello \& Ratti (2009), Govers (2011), \& Drill (2016). The samples were from Ulaanbaatar Mongolia. This city was built in middle of 20 centuries which is a new city in the world. The previous studies researched on the historical big metropolis but Ulaanbaatar Mongolia only with one million five thousand populations which is relative young and smaller city but the capital city in Mongolia. City reputation is not so significant than other metropolis in previous studies.

The $\mathrm{H}_{2}$ had been supported by Malthouse et al. (2004), Gearing (1974), Coviello, Winklhofer, \& Hamilton (2006), the result of $\mathrm{H}_{2}$, City infrastructure positively impacts on tourists' satisfaction. The only one hypothesis was supported. By the government paying more attention to visitors' accommodation, safety, and health; to create a tourist information center and to the most visited tourist destinations, which is information and accompanying services are provided to tourists and local residents, which shows that tourists are satisfied.

According to city attraction framework which demonstrated by Prayag and Ryan, 2012; Ramkissoon, 2013; Veasna; 2013; Yuksel \& Yuksel (2010), the results supported $\mathrm{H}_{3}$. But in this study $\mathrm{H}_{3}$ :City attraction positively impacts on tourists' satisfaction, which was rejected. For foreign tourists visiting in Mongolia, they are not really interesting about city, they more interested nomadic culture, and wants to seeing the unique setting landscapes of countryside.

Rejecting $\mathrm{H}_{4}$ : Workforce of city positively impacts on tourists' satisfaction, in this study can be explained by following reasons. The residents are very friendly to tourists and the shop, shopping centers service is good, but the lack of language knowledge, so getting languages problems among tourists and workers.

$\mathrm{H}_{5}$ : City economic positively impacts on the tourists' satisfaction, and the $\mathrm{H}_{5}$ was not supported, which had been supported by Tulyeu,(2012) and Zhou, Liu, Tang, (2018). The reasons can be explained bythere are few complex tourism centers that to relax or leisure time or shopping when the tourists who come to visit the city or stay in the city also the main problem facing them is a language problem when a purchase or get service.

$\mathrm{H}_{6}$ : Street Marketing has positively impacts on tourists' satisfaction. The results did not support $\mathrm{H}_{6}$ which had been supported bySandybayev, (2018).In this study can be explained by following reasons, that the streets of Ulaanbaatar has well lighting and sign but the most serious problem is trash and sometimes the lack of toilet facilities. 
$\mathrm{H}_{7}$ : Destination Marketing has positively impacts on tourists' satisfaction, was not supported in this study can be explained by following reasons. Because Ulaanbaatar city is a young town, some of the tourist destinations were lack of characteristic features also lack value or image of the difference between other places.

\subsection{Recommendation}

From the results of this study, consider a number of factors, there are identified some recommendations for the tourism sector who running business. Ulaanbaatar city is the main center of Mongolia, which is political, economic, social and cultural. The number of tourists visiting in Mongolia has been relatively stable over the past 10 years and the main product of our tourism industry is a natural landscape, traditional Mongolian culture, and customs, which is attracted by tourists as the history of nomadic culture, beautiful nature, and history of Mongolia and Chinggis Khaan. Approximately $70 \%$ of tourists visiting in Mongolia, they are interested in the scenic nature and often travel through the countryside, also 98\% of all tourists visited through Ulaanbaatar.The most important thing in the results of this study is that need to promoting the urban culture for residents and it is necessary to take into account the language proficiency of the service sector workers. In Ulaanbaatar, there are few streets with their own culture which needs to support street art also the survey results showed that need to rebuild the night street based on created by other major cities standard with attracting commercial or tourist attractions. Also, there is an idea to encourage youth participation depends on their expressing views and provides opportunities for their contribution to the city, which organize street performances, events, and activities that attract tourists and residents. This study need for promoting to the cooperation between the public and private sector to bring new changes developing tourism, with the consistent policy, legislation, that modern tourism requirement. For future research, I would suggest to expand the research by comparing the difference between urban and rural disparities in the satisfaction of tourists and loyalty, which may be show more interesting result.

\section{References}

Anon (2008). An idea can change a brand's life. [Online] Available from: http://www. indiaretailing.com/news.asp?id=2382\&topic=3(August27,2008)

Baker, D. A. \& Crompton, J. L. (2000), Quality, satisfaction and behavioral intentions. Annals of Tourism Research, 27, 785-804.

Blain, C., Levy, S. E., \& Ritchie, J. R. B. (2005), Destination branding: insights and practices from destination management organizations. Journal of Travel Research, 43(4), 328-338.

Braun, E. (2008), City Marketing: Towards an Integrated Approach, PhD thesis, ERIM, Erasmus School of Economics.

Chang, C. (2013). Imagery fluency and narrative advertising effects. Journal of Advertising, 42(1), 54-68. doi:10.1080/00913367.2012.749087

Chiang, Y. C., Weng, P. Y., \& Chang, C. Y. (2012). Influences of Green Space Structure and Residential Environment Quality on Living Satisfaction, Journal of Landscape Architecture (Taiwan), 18(3), 21-41.

Crouch, G. (2011). Destination competitiveness: An analysis of determinant attributes. Journal of Travel Research, 50 (1), 27.

Coban, S. (2012). The effects of the image of destination on touristsatisfaction and loyalty: the case of Cappadocia. European Journal of Social Science, 2(29), 222-232.

Cova, B., \&Saucet, M.(2014), The secret lives of unconventional campaigns: Street marketing on the fringe. Journal of Marketing Communications, 21(1), 65-77.

Conejo, Francisco,\&Wooliscroft, B. (2015). Brands defined as semiotic marketing systems. Journal of Macromarketing, 35(3), 287-301.

Coviello, Winklhofer,H\&Hamilton, K. (2006). Marketing practices and performance of small service firms: An examination in the tourism accommodation sector. Journal of Service Research, 9(1), 38-58.

Deas, I \& Giordano, B. (2001).Conceptualising and measuring urban competitiveness in major English cities: An exploratory approach Environment and Planning A, 33(8), 1411-1429. Drill, N. (2016), Transportation Research Procedia, 16, 46-53

Enkhzaya, E. (2014), Compilation of National Statistical Office,The population of Ulaanbaatar,Economic activity,Economic Statistics Divisionof Capital City Statistical Office.

Ferrer, A. L. C., Thomé, A. M. T., \&Scavarda, A. J. (2018). Sustainable urban infrastructure: A review. Resources, Conservation and Recycling, 128, 360372.

Gearing, C.E. (1974). Establishing a measure of touristic attractiveness. Journal of Travel Research 12, 1-8. 
Goletti, F., \& Christina-Tsigas, E. (1995). Analyzing market integration in prices, products and people: Analyzing agricultural markets in developing countries. (ED Gregory J. Scott) Published in cooperation with the International Potato Center (CIP).

Gossett. D. (2019), 9 Great Urban Marketing Tactics. [Online] Available: https://salespromotions.org/9-great-urbanmarketing-tactics/ (Apr 17, 2019)

Govers,R. (2011). From place marketing to place branding and back. Place Branding and Public Diplomacy, 7, 227231.

Hanafiah, M. H., Hemdi, M., \&Ahmad, M. A. I. (2016).Tourism destination competitiveness, Tourism Economics, 22 (3), 629-636.

Hsing, Y. (2010), The Great Urban Transformation: Politics of Land and Property in China. Oxford: Oxford University Press, (Chapter 1, Chapter 2, Chapter 4).

Hunt, H. K. (Ed.).(1977).Conceptualization and measurement of consumersatisfaction and dissatisfaction). Marketing Science Institute, Massachusets. 77-103.

Kotler, P., Asplund, C., Rein, I.\& Heider, D.(1999). Marketing places Europe: Attracting investments, industries, residents and visitors to European cities, communities, regions and nations, Pearson Education, London, UK

Kotler, P \&Gertner, D. (2002). Country as Brand, Product, and Beyond: A Place Marketing and Brand Management Perspective, The Journal of Brand Management. 9, 249-261.

Kotler, P., \& Keller, K. L. (2007). Marketing Management. (12th ed.). Prentice-Hall of India, (Chapter4)

Koster, A. (1994),Urban marketing - A new approach for town planning and a chance for reactivation of sites in oldindustrial regions, Urban Marketing in Europe - International Conference, Torino Incontra, Torino.

Kozak, M., \&Rimmington, M. (2000). Tourist satisfaction with Mallorca, Spain, as an off-season holiday destination. Journal of Travel Research, 38, 260-269.

Lacobucci, D., \& Ostrom, A. (1996). Perceptions of services. Journal of Retailing and Consumer Services, 3(4), 195212.

Levinson, Jay (1998). Guerrilla marketing. New York, New York: Houghton Mifflin Company, 1-89. ISBN 978-0395-90625-5

Malthouse, Edward C., James L. Oakley, Bobby J. Calder, \& Dawn Iacobucci. (2004). Customer satisfaction across organizational units. Journal of Service Research 6 (3), 231-242.

Meyer, P. A. (1999), How responsive is business capital formation to its user cost?: An exploration with micro data. Journal of Public Economics, 74(1), 53-80.

Morgan, N., Pritchard, A., Pride, R. (2004), Destination branding - Creating the unique destination proposition, (2nd ed), Butterworth-Heinemann, Oxford.

Morrello, E., Ratti, C. (2009). A digital image of the city: 3D isovists in Lynch's urban analysis. Environment and Planning B: Planning and design, 36, 837-853.

Moscardo, Gianna. (2017). Exploring mindfulness and stories in tourist experiences. International Journal of Culture, Tourism and Hospitality research 11 (2), 111-124.

National Statistics Office of Mongolia,[Online] Available: http://www.1212.mn/tables.aspx?tbl_id=DT_NSO_0300_003V1\&SEX_select_all=1\&SEXSingleSelect=\&AG E_GROUP5_select_all=0\&AGE_GROUP5SingleSelect=_1\&Year_select_all=0\&YearSingleSelect=\&viewtyp $\mathrm{e}=$ table

Online Survey Monkey. Retrieved from https://www.surveymonkey.com/r/85HV2GV

Prayag, G \& Ryan, C. (2012). Antecedents of tourists' loyalty to mauritius the role and influence of destination image, place attachment, personal involvement, and satisfaction. Journal of Travel Research, 51, 342-356.

Prideaux, B. (2000), The role of the transport system in destination development. Tourism Management, 21, 53-63

Rajesh, R. (2013). Impact of tourist perceptions, destination image and tourist satisfaction on destination loyalty: a conceptual model. PASOS, 11(3), 67-78.

Ramkissoon, H, Weiler, B \& David, L., G., S. (2012). Place attachment and pro-environmental behavior in national parks: the development of a conceptual framework. Journal of Sustainable Tourism, 20(2), 257276.https://doi:10.1080/09669582.2011.602194

Ritchie, J. R. B., Crouch, G. I. (2003). The competitive destination: A sustainable tourism perspective, CABI Pub, New York, NY.

Sandui, Ts. (2015), The city is like living organisms. [Online] Available: http://vip76.mn/content/31215. (April 13, 2015)

Sandybayev, A.(2018). The impact of street and food festivals in gastronomic tourism through visitor's emotions and satisfaction: A case of Abu Dhabi food festival. International Journal of Research in Tourism and Hospitality (IJRTH) 4(1),27-32. 
Susskind, Alex, M., Carl, P. (2000), Customer service behavior and attitudes among hotel managers: A look at perceived support functions, standards for service, and service process outcomes. Journal of Hospitality \& Tourism Research 24 (3), 373-397.

Tulyeu, O. (2012), Some issues related to interbank balance management,Mongolia's economy,Compilation of business research scientific conference, 210.

Truong, T.L.H. \&Lenglet, F. \&Mothe, C. (2017). Destination distinctiveness: Concept, measurement, and impact on tourist satisfaction. Journal of Destination Marketing \& Management.

Van der Meer J. (1990), The Role of City Marketing in Urban Management, Rotterdam, European Institute for Comparative Urban Research Erasmus University

Veasna S., Wu W. Y., \& Huang C. H. (2013). The impact of destination source credibility on destination satisfaction: the mediating effects of destination attachment and destination image. Tour. Manage, 36, 511-526. https://doi:10.1016/j.tourman.2012.09.007

Walsh, F., (2006). Strengthening Family Resilience. (2nd ed.). New York: Guilford Press, (384pp).

Wang, Y., Lo, H.P., \& Hui, Y.V.(2003), The antecedents of service quality and product quality and their influences on bank reputation: evidence from the banking industry in China. Managing Service Quality: An International Journal,13(1),72-83.

Ward, S. V. (1998), Selling Places: The marketing and promotion of towns and cities, 1850-2000, E \& FN Spon, London, UK.

Woodside, A.G., Frey, L.L,\& Daly, R.T. (1989), Linking service quality, customer satisfaction, and behavioral intention. Journal of Health Care Marketing, 9(4), 5-17.

Yuksel, A.,\&Yuksel, F. (2001). The expectancy-disconfirmation paradigm: A critique. Journal of Hospitality \& Tourism Research, 25(2), 107-131.

Zhang,L.\&Zhao, S.X. (2009), City branding and olympic effect: A case study of Beijing. Cities,25,245-254.

Zhou, M., Liu, X., Tang, G. (2018), Effect of urban tourist satisfaction on urban macroeconomics in China: A spatial panel econometric analysis with a spatial Durbin model. PLoS ONE 13(10), e0206342. https://doi.org/10.1371/journal.pone.0206342 